\title{
PENGANGGURAN STRUKTURAL: FAKTOR YANG MEMPENGARUHI DAN DINAMIKANYA
}

\author{
Tarsidin $^{1}$
}

\begin{abstract}
This paper investigates the persistence of unemployment in Indonesia, by decomposing unemployment into structural and cyclical unemployment and exploring its determinants and dynamics. The result shows that currently Indonesia is experiencing structural unemployment, which is caused by structural change of Indonesian economy. Factors contributing to the structural unemployment include sectoral labor productivity and sectoral real wage, beside specific skill required by the sectors. The study reveals the need for a good economic planning to avoid unemployment in the future.
\end{abstract}

JEL Classification: J21, J23, J31

Keywords: Structural unemployment, labor productivity, real wage

1 Tarsidin adalah mahasiswa program doktor Ilmu Ekonomi pada Fakultas Ekonomi Universitas Indonesia; email: tarsidin@yahoo.co.id 


\section{PENDAHULUAN}

Pengangguran merupakan salah satu agenda Pemerintah yang mendesak untuk ditanggulangi. Sejak Indonesia mengalami krisis ekonomi pada tahun 1997, jumlah pengangguran terus naik, sebagaimana ditunjukkan pada Lampiran. Meskipun pada beberapa tahun terakhir terjadi penurunan, saat ini jumlah penganggur masih besar, yakni sekitar 9,5 juta orang penganggur. Sebagaimana diketahui terdapat beberapa kategori pengangguran, yakni frictional unemployment, structural unemployment, dan cyclical unemployment. Di tengah kinerja perekonomian Indonesia yang terus membaik, ditandai dengan stabilitas kondisi ekonomi makro dan pertumbuhan ekonomi yang relatif tinggi, kenyataan bahwa jumlah pengangguran terus bertambah tentunya menjadi hal yang patut dicermati. Diperkirakan pengangguran tersebut sebagian besar merupakan structural unemployment, sementara cyclical unemploymentnya relatif kecil.

Jika kita cermati, terjadi pergeseran yang cukup signifikan atas struktur perekonomian Indonesia. Sebagaimana ditunjukkan pada Lampiran, beberapa sektor usaha mengalami peningkatan share terhadap total GDP, sementara sektor-sektor usaha lainnya ada yang turun atau pun relatif konstan. Sektor usaha yang mengalami peningkatan share antara lain sektor industri pengolahan, dari semula share-nya sebesar 23,46\% pada tahun 1993 menjadi 27,84\% pada tahun 2006, dan sektor pengangkutan dan komunikasi, dari semula share-nya 4,52\% pada tahun 1993 menjadi 6,74\% pada tahun 2006. Sedangkan sektor usaha yang mengalami penurunan terutama sektor pertanian, dari semula share-nya sebesar 16,77\% pada tahun 1993 menjadi 14,15\% pada tahun 2006. Perubahan struktur perekonomian tersebut tentunya dapat memicu timbulnya pengangguran, berupa structural unemployment.

Perubahan struktur perekonomian tersebut diperkirakan menyebabkan terjadinya pergeseran pada beberapa hal, yakni pada demand dan supply atas tenaga kerja dengan kemampuan/keahlian tertentu di labor market, perubahan produktivitas tenaga kerja di masingmasing sektor usaha, dan besarnya upah (riil) di masing-masing sektor usaha. Ketiga faktor tersebut akan saling berinteraksi dan menentukan besarnya employment dan pengangguran di masing-masing sektor usaha. Berdasarkan hal tersebut, menarik kiranya untuk dilakukan penelitian mengenai pengaruh perubahan struktur perekonomian terhadap tingginya tingkat pengangguran di Indonesia. Mengingat tidak tersedianya data mengenai kemampuan/keahlian tenaga kerja sektoral, maka hanya faktor produktivitas tenaga kerja dan tingkat upah sektoral yang akan diteliti.

Studi/penelitian ini diharapkan dapat menjawab beberapa pertanyaan tentang pengaruh perubahan struktur perekonomian Indonesia terhadap produktivitas tenaga kerja dan besarnya 
upah di masing-masing sektor usaha, pengaruh perubahan produktivitas tenaga kerja dan besarnya upah di masing-masing sektor usaha tersebut terhadap besarnya tingkat pengangguran di Indonesia, dan pengaruh perubahan struktur perekonomian Indonesia terhadap tingkat pengangguran di Indonesia.

Tujuan studi/penelitian ini meliputi hal-hal sebagai berikut: mendapatkan gambaran mengenai pengaruh perubahan struktur perekonomian Indonesia terhadap produktivitas tenaga kerja dan besarnya upah di masing-masing sektor usaha; mendapatkan gambaran mengenai pengaruh perubahan produktivitas tenaga kerja dan besarnya upah di masing-masing sektor usaha terhadap tingkat pengangguran di Indonesia, yakni dengan melihat dinamika sektorsektor usaha dalam merespon kedua faktor tersebut; serta mendapatkan gambaran mengenai pengaruh perubahan struktur perekonomian terhadap tingkat pengangguran, dan sektor-sektor usaha manakah yang paling besar menimbulkan peningkatan jumlah penganggur. Dengan mengetahui secara tepat penyebab pengangguran di Indonesia, diharapkan Pemerintah dapat mengambil langkah-langkah yang lebih efektif untuk menekan jumlah pengangguran.

Tulisan ini akan diketengahkan sebagai berikut. Bagian II berisi tinjauan atas beberapa studi yang telah dilakukan dan model yang akan digunakan dalam penelitian ini; Bagian III berisi metode dan data; Bagian IV berisi analisis dan pembahasan; dan bagian $\vee$ berisi kesimpulan dan rekomendasi.

\section{TEORI}

Beberapa penelitian berusaha mendekomposisi besarnya pengangguran berdasarkan faktor-faktor penyebabnya. R.A. Gordon, sebagaimana disebutkan Stoikov (1966), mengajukan pendekatan dengan menggunakan besaran relative unemployment rate (rasio tingkat pengangguran sektoral terhadap tingkat pengangguran nasional), porsi angkatan kerja sektoral, dan kontribusi sektoral atas besaran pengangguran agregat, dalam memisahkan pengangguran yang disebabkan faktor siklikal dan faktor struktural. Namun metode ini memiliki keterbatasan, mengingat perbandingan antar dua periode harus dilakukan pada periode di mana pengangguran yang disebabkan faktor siklikal berada pada level minimumnya.

\section{II.1. Faktor-faktor Penyebab Structural Unemployment}

Baik frictional unemployment maupun structural unemployment dapat terjadi ketika perekonomian berada pada full employment, besaran keduanya menunjukkan natural rate of unemployment, sebagaimana disebutkan Lipsey, Courant, dan Ragan (1999). Structural 
unemployment terjadi karena adanya penyesuaian atau perubahan struktur perekonomian, di samping karena adanya beberapa faktor institusional lainnya.

Beberapa studi terkait dengan structural unemployment antara lain diketengahkan oleh Poloz (1994), yang meneliti sebab-sebab pengangguran di Canada. Seiring dengan perubahan perekonomian, terjadi proses penyesuaian antara supply dan demand atas tenaga kerja dengan keahlian tertentu. Pengangguran terjadi karena adanya pergeseran permintaan tenaga kerja inter-sektoral dan proses realokasi tenaga kerja antar sektor usaha yang lambat. Di samping itu beberapa faktor struktural (institusional) lain yang berpengaruh berupa faktor demografi, asuransi pengangguran, labor market hysteresis, upah minimum, serikat pekerja, dan pajak penghasilan. Sementara itu Cassino dan Thornton (2002) melakukan studi atas hubungan antara natural rate of unemployment dan perubahan struktur perekonomian UK. Beberapa faktor struktural (institusional) yang berpengaruh antara lain: replacement ratio, banyaknya serikat pekerja, dan unemployment mismatch.

Blien dan Sanner (2006) menyebutkan bahwa peningkatan produktivitas pada industriindustri tertentu dapat mempunyai efek positif atau pun negatif terhadap employment, tergantung pada besaran labor-saving dan labor-augmenting effect-nya. Peningkatan produktivitas melalui technological progress, yang berdampak pada labor-saving, dapat menyebabkan tingginya pengangguran, bila besarannya tidak dapat dikompensasi oleh laboraugmenting effect atas peningkatan permintaan agregat dengan turunnya harga barang seiring dengan naiknya produktivitas. Pada penelitian tersebut produkvitas diukur dari technological progress, bukan dari produkvitas tenaga kerjanya.

Sementara itu Reder (1964) dalam penjelasannya tentang hubungan antara struktur upah dan structural unemployment, menyebutkan bahwa occupational wage differential turut berpengaruh terhadap besaran structural unemployment. Namun dalam hal ini analisis lebih pada perilaku employer dan pekerja dengan jenis pekerjaan tertentu, bukan pada pengaruh perbedaan upah antar sektor usaha terhadap structural unemployment.

Helwege (1992) menyebutkan bahwa perbedaan upah antar sektor usaha antara lain terjadi karena adanya industry-specific shocks atas permintaan tenaga kerja yang bersifat temporer. Sedangkan Lee dan Pesaran (1993) dalam analisisnya tentang penentuan upah menyebutkan bahwa perubahan upah relatif (sektoral) merefleksikan perubahan struktural yang tengah berlangsung dalam suatu perekonomian. Perbedaan upah antar sektor usaha yang antara lain disebabkan oleh perubahan struktur perekonomian tersebut diperkirakan bisa berdampak pada structural unemployment. 


\section{II.2. Dinamika Structural Unemployment}

Dinamika structural unemployment antara lain diteliti oleh Neelin (1987), yang melakukan pengujian atas hipotesis bahwa perubahan employment sektoral (yang sangat ditentukan oleh perubahan permintaan tenaga kerja sektoral) akan berpengaruh pada besaran pengangguran agregat. Dalam pengujiannya dipisahkan antara perubahan employment sektoral yang disebabkan oleh shock yang bersifat agregat (yang dampaknya dirasakan oleh seluruh sektor usaha), dan yang hanya terjadi pada sektor usaha tertentu saja. Hasil studinya menunjukkan bahwa perubahan permintaan tenaga kerja sektoral yang bersifat eksogen (tidak berkorelasi dengan perekomomian agregat) tidak mempunyai pengaruh yang signifikan terhadap tingkat pengangguran agregat, berbeda dengan perubahan permintaan tenaga kerja sektoral yang disebabkan oleh shock yang bersifat agregat.

Di sisi lain, Riordan dan Staiger (1993) menyebutkan bahwa sectoral shock dapat menyebabkan structural unemployment jika employer di sektor usaha yang mengalami penurunan kegiatan mempunyai informasi lebih banyak tentang kualitas pekerjanya dibandingkan employer di sektor usaha yang mengalami peningkatan kegiatan. Hal ini akan menyebabkan pekerja-pekerja tersebut terpaksa menganggur meskipun mereka sebenarnya mempunyai kualitas baik dan memiliki produktivitas tinggi jika dipekerjakan di sektor usaha yang mengalami peningkatan kegiatan usaha.

\section{II.3. Model}

Dari beberapa penelitian tersebut di atas, diketahui banyak faktor yang menjadi penyebab pengangguran, antara lain disebabkan shock variabel-variabel ekonomi makro, faktor institusional (labor market), dan perubahan struktur perekonomian. Sebagaimana dikemukakan di muka, terdapat beberapa jenis pengangguran sesuai dengan faktor-faktor penyebabnya, yakni frictional unemployment, structural unemployment, dan cyclical unemployment. Dengan demikian besarnya pengangguran di suatu perekonomian dapat diformulasikan sebagai berikut:

$$
U=U_{f}+U_{s}+U_{e}
$$

di mana:

$$
\begin{array}{ll}
U & : \text { total unemployment } \\
U_{f} & : \text { frictional unemployment } \\
U_{s} & : \text { structural unemployment } \\
U_{e} & : \text { cyclical unemployment }
\end{array}
$$


Pada penelitian ini perhatian akan difokuskan pada structural unemployment, yang disebabkan oleh adanya perubahan struktur perekonomian. Sebagaimana disebutkan pada beberapa literatur di atas, terdapat beberapa faktor struktural (institusional) yang menyebabkan terjadinya structural unemployment. Namun pada penelitian ini akan digunakan pendekatan yang sedikit berbeda, yakni dengan menitikberatkan pada tiga faktor yang secara langsung terkait dengan perubahan struktur perekonomian, yakni: mismatch dalam hal kemampuan/ keahlian tenaga kerja yang tersedia di pasar dan yang dibutuhkan (kemampuan/keahlian tenaga kerja sektoral), produktivitas tenaga kerja sektoral, dan tingkat upah sektoral. Dengan demikian structural unemployment tersebut dapat dirumuskan sebagai berikut:

$$
U_{s}=\alpha \Phi+\gamma \Omega+\lambda w
$$

di mana:

$$
\begin{array}{ll}
U_{s} & : \text { structural unemployment } \\
\Phi & : \text { vektor kemampuan tenaga kerja sektoral } \\
\Omega & : \text { vektor produktivitas tenaga kerja sektoral } \\
w & : \text { vektor tingkat upah sektoral }
\end{array}
$$

Kontribusi penelitian ini terletak pada dimasukkannya variabel produktivitas tenaga kerja sektoral dan perbedaan tingkat upah sektoral sebagai faktor yang mempengaruhi besaran structural unemployment. Beberapa penelitian sebelumnya menyebutkan bahwa peningkatan produktivitas yang disebabkan oleh technological progress-lah yang mempengaruhi tingkat pengangguran, bukan produktivitas tenaga kerja sektoral. Di samping itu pada penelitian sebelumnya, disebutkan bahwa perbedaan tingkat upah yang mempengaruhi besarnya pengangguran adalah perbedaan tingkat upah berdasarkan jenis pekerjaan, bukan perbedaan tingkat upah sektoral.

\section{METODOLOGI}

Mengingat ketidaktersediaan data kemampuan/keahlian tenaga kerja sektoral maka model structural unemployment yang akan diuji hanya meliputi faktor produktivitas tenaga kerja sektoral dan perbedaan tingkat upah sektoral. Beberapa hal terkait dengan pengumpulan data dan metodologi penelitiannya dapat diketengahkan sebagai berikut.

\section{III.1. Data}

Periode observasi penelitian ini dari tahun 1993 - 2006, berupa data tahunan. Data yang diperlukan diperoleh dari publikasi CEIC, BPS, Bank Indonesia, dan dari berbagai publikasi lainnya. Beberapa data yang digunakan antara lain: 


\section{Employment sektoral}

Mengingat ketidaktersediaan data pengangguran sektoral, maka akan digunakan mirror data-nya, yakni data employment sektoral, dalam menjelaskan structural unemployment. Besaran data employment sektoral yang digunakan berupa rasio antara besarnya employment di suatu sektor usaha terhadap keseluruhan employment dalam suatu perekonomian (employment share sektoral). Dengan demikian modelnya pun akan disesuaikan.

Penggunaan mirror data ini didasarkan pada kenyataan bahwa kenaikan/penurunan employment di suatu sektor usaha akan menyebabkan penurunan/kenaikan pengangguran di sektor usaha yang bersangkutan. Memang tenaga kerja dapat bekerja di sektor usaha mana saja, dan dengan demikian penganggur tidak dapat diklaim sebagai penganggur pada sektor usaha tertentu. Namun dalam hal ini penganggur dapat dinyatakan berasal dari sektor usaha tertentu, yakni sektor usaha di mana sebelumnya penganggur tersebut bekerja. Hal ini berarti pengaruh produktivitas tenaga kerja sektoral, perbedaan tingkat upah sektoral, dan explanatory variable lainnya terhadap employment sektoral akan merefleksikan pengaruh variabel-variabel tersebut terhadap unemployment sektoral, yang menunjukkan besaran structural unemployment.

2. Produktivitas tenaga kerja sektoral

Produktivitas tenaga kerja sektoral diukur sebagai berikut:

$\Omega_{i}=\frac{y_{i}}{L_{i}}$

di mana:

$\Omega_{i} \quad$ : produktivitas tenaga kerja sektor usaha i

$y_{i} \quad$ : GDP riil sektor usaha i

$L_{i} \quad$ : jumlah labor yang dipekerjakan di sektor usaha i

Mengingat GDP riil sektor usaha i pada dasarnya merupakan value added sektoral, maka pengukuran produktivitas tenaga kerja tersebut mengukur besarnya produktivitas dari value added, bukan dari gross output. Sebagaimana disebutkan OECD (2001), kelemahan dari ukuran produktivitas tenaga kerja adalah bahwa ukuran tersebut merupakan ukuran produktivitas parsial, yang sebenarnya merefleksikan pengaruh dari beberapa faktor, seperti capital intensity di sektor usaha tersebut atau pun adanya substitusi kapital terhadap labor.

3. Tingkat pendidikan tenaga kerja Variabel tingkat pendidikan diperlukan sebagai control variable pada pemodelan pengaruh 
perubahan share GDP riil sektoral terhadap tingkat produkvitias tenaga kerja sektoral. Data yang digunakan adalah persentase jumlah penduduk berusia 10 tahun ke atas yang menyelesaikan pendidikan menengah atas (secondary schooling). Namun mengingat tidak tersedianya data sektoral, digunakan data nasional yang sama untuk semua sektor usaha.

4. Upah riil sektoral

Data upah yang tersedia berupa data upah nominal sektoral dari Departemen Tenaga Kerja dan Transmigrasi, dari tahun 1991- 2003, dengan missing data pada beberapa tahun di antaranya. Pendekatan yang dilakukan adalah dengan melakukan interpolasi dan ekstrapolasi untuk mendapatkan estimasi besaran missing data dan besaran upah pada tahun 2004 2006. Kemudian besaran upah nominal tersebut di-discounted dengan CPI tahun dasar 2000 untuk mendapatkan besaran upah riil sektoral. Kemudian besarannya dikalikan dua belas untuk mendapatkan upah riil sektoral tahunan.

5. GDP riil sektoral

Data ini diperlukan untuk menghitung besaran perubahan struktur perekonomian, yang diukur dari perubahan besarnya share GDP riil suatu sektor usaha terhadap total GDP riil Indonesia. Dalam hal ini digunakan GDP pada harga konstan dengan tahun dasar 2000.

6. Pertumbuhan ekonomi sektoral

Data pertumbuhan ekonomi sektoral diperlukan dalam menganalisis besaran cyclical unemployment. Pertumbuhan ekonomi sektoral tersebut merupakan pertumbuhan GDP riil sektoral.

\section{III.2. Metode}

Dalam hal ini digunakan metode panel data untuk mengestimasinya. Dalam melakukan regresi, di samping dilakukan regresi dengan common coefficient, dilakukan pula regresi crosssection specific coefficient guna mendapatkan gambaran atas perbedaan perilaku sektoral. Untuk mendapatkan hasil regresi terbaik, akan dilakukan F-test dan Hausman test guna melihat metode panel data mana yang paling tepat, apakah pooled least squre, fixed effect model, ataukah random effect model.

Beberapa langkah akan dilakukan dalam menganalisis besaran, faktor-faktor yang mempengaruhi, dan dinamika structural unemployment di Indonesia. Langkah pertama, adalah mengukur berapa besar pengangguran yang disebabkan oleh perubahan struktur 
perekonomian (structural unemployment) tersebut. Hal ini dilakukan melalui regresi atas model berikut:

$$
E_{i, t}=\mu+\varphi s_{i, t}+\eta \hat{y}_{i, t}+e_{i, t}
$$

di mana:

$E_{i} \quad$ : employment share sektoral

$\mu \quad$ : intercept

$s_{i, t} \quad$ : share GDP riil sektoral

$\hat{y}_{i, t} \quad$ : pertumbuhan GDP riil sektoral

Dari regresi tersebut dapat dilihat pengaruh kenaikan/penurunan share GDP riil sektoral terhadap turun/naiknya pengangguran (menunjukkan pengaruhnya terhadap structural unemployment), tentunya dengan mengontrol beberapa variabel yang turut berpengaruh terhadap naik/turunnya pengangguran, dalam hal ini tingkat pertumbuhan ekonomi (yang menunjukkan pengaruhnya terhadap cyclical unemployment). Sebagaimana disebutkan di muka, kenaikan/penurunan employment di suatu sektor usaha merefleksikan penurunan/kenaikan pengangguran di sektor usaha yang bersangkutan.

Langkah kedua, adalah menganalisis pengaruh perubahan struktur perekonomian terhadap produktivitas tenaga kerja dan upah riil tenaga kerja sektoral, melalui regresi sebagai berikut:

$$
\Omega_{i, t}=\beta+\delta s_{i, t}+\omega E d_{i, t}+e_{i, t}
$$

di mana:

$\Omega_{i} \quad$ : produktivitas tenaga kerja sektoral

$E d_{i} \quad$ : tingkat pendidikan tenaga kerja sektoral

$s_{i, t} \quad$ : share GDP riil sektoral

dan

$$
w_{i, t}=\phi+\sigma s_{i, t}+\bar{w}_{t}+e_{i, t}
$$

di mana:

$w_{i} \quad$ : upah riil tenaga kerja sektoral

$\bar{w} \quad$ : upah rill tenaga kerja rata-rata

$s_{i, t} \quad$ : share GDP riil sektoral

Langkah selanjutnya adalah menganalisis pengaruh perubahan produktivitas tenaga kerja dan tingkat upah riil sektoral terhadap besarnya structural unemployment. Dalam hal ini 
pengaruh pertumbuhan GDP riil sektoral terhadap employment dikontrol dengan memasukkannya sebagai salah satu variabel. Pengaruh terhadap besarnya pengangguran sektoral direfleksikan oleh pengaruhnya terhadap employment share sektoral. Hal ini dilakukan melalui regresi sebagai berikut:

$$
E_{i, t}=\alpha+\gamma \Omega_{i, t}+\lambda w_{i, t}+\eta \hat{y}_{i, t}+e_{i, t}
$$

di mana:

$E_{i} \quad$ : employment share sektoral

$\Omega_{i} \quad$ : produktivitas tenaga kerja sektoral

$w_{i} \quad$ : upah riil tenaga kerja sektoral

$\hat{y}_{i, t} \quad$ : pertumbuhan GDP riil sektoral

\section{ANALISIS}

Sebagaimana disebutkan di muka, terdapat beberapa tahapan yang dilakukan dalam menganalisis besaran, faktor-faktor yang mempengaruhi, dan dinamika structural unemployment di Indonesia. Hasil regresi atas model-modelnya dapat dijelaskan sebagai berikut.

\section{IV.1. Dekomposisi Unemployment}

Hasil regresi atas model $E_{i, t}=\mu+\varphi s_{i, t}+\eta \hat{y}_{i, t}+e_{i, t}$ terlebih dahulu diuji dengan F-test dan Hausman test. Berdasarkan pengujian dengan F-test, guna menentukan model terbaik di antara pooled LS dan fixed effect, terlihat bahwa nilai F-statistiknya 15,68, sementara itu F-tabel dengan $\mathrm{v} 1=8$ dan $\mathrm{v} 2=115$ pada level of significance $5 \%$ adalah 2,02. Dengan demikian fixed effect model lebih dipilih daripada pooled LS. Sementara itu hasil pengujian dengan Hausman test menghasilkan besaran Chi-square yang negatif, yakni sebesar -6,99, dengan demikian tidak signifikan untuk menolak Ho bahwa random effect dan fixed effect sama saja. Mengingat adanya kemungkinan korelasi antara unobserved/time-constant factors dan explanatory variables, dalam hal ini dipilih untuk menggunakan fixed effect model.

Sebagaimana ditunjukkan pada tabel di atas, terlihat bahwa share GDP riil sektoral berpengaruh negatif terhadap penyerapan tenaga kerja, sehingga peningkatan share GDP riil suatu sektor usaha justru cenderung meningkatkan pengangguran. Sementara itu pertumbuhan GDP riil sektoral berpengaruh positif terhadap penyerapan tenaga kerja, atau dengan kata lain pertumbuhan GDP riil akan mengurangi pengangguran. Nilai adjusted R-squared-nya yang sebesar 0,98 menunjukkan bahwa model tersebut dapat menjelaskan variasi pada employment 


\begin{tabular}{|c|c|c|}
\hline \multicolumn{3}{|c|}{$\begin{array}{c}\text { Tabel II.1 } \\
\text { Dekomposisi Unemployment }\end{array}$} \\
\hline \multicolumn{3}{|c|}{$\begin{array}{c}\text { Dependent Variable: Employment Share Sektoral } \\
\text { Periode observasi: } 1993 \text { - } 2006 \\
\text { Metode: Fixed Effect }\end{array}$} \\
\hline \multirow[b]{2}{*}{ Sektor Usaha } & \multicolumn{2}{|c|}{ Explanatory Variables } \\
\hline & $\begin{array}{l}\text { Share GDP Riil } \\
\text { Sektoral } \\
\text { (SHAREGDP) }\end{array}$ & $\begin{array}{l}\text { Pertumbuhan GDP Riil } \\
\text { Sektoral } \\
\text { (GDPGROWTH) }\end{array}$ \\
\hline \multicolumn{3}{|c|}{ Model I: Common Coefficient } \\
\hline Sektor-sektor Usaha & $\begin{array}{l}-0,035782 * * * \\
(0,012526)\end{array}$ & $\begin{array}{l}0,006957 * * * \\
(0,000481)\end{array}$ \\
\hline Adjusted $\mathrm{R}^{2}$ & 0,982733 & \\
\hline F-statistic & $601,1888 * * *$ & \\
\hline DW-statistic & 2,353467 & \\
\hline \multicolumn{3}{|c|}{ Model II: Cross-Section Specific Coefficient } \\
\hline Pertanian & $\begin{array}{l}1,512714 \\
(1,301158)\end{array}$ & $\begin{array}{l}-0,095843 \\
(0,449652)\end{array}$ \\
\hline Penggalian dan Pertambangan & $\begin{array}{l}-0,101669 * * * \\
(0,009434)\end{array}$ & $\begin{array}{l}-0,008538 * * * \\
(0,001482)\end{array}$ \\
\hline Industri Pengolahan & $\begin{array}{l}-0,324241 \\
(0,270630)\end{array}$ & $\begin{array}{l}0,087437 * * * \\
(0,011625)\end{array}$ \\
\hline Listrik, Gas, dan Air Bersih & $\begin{array}{l}0,188855^{\star * *} \\
(0,024035)\end{array}$ & $\begin{array}{l}0,008279 * * * \\
(0,000132)\end{array}$ \\
\hline Bangunan & $\begin{array}{l}0,302650 * * * \\
(0,070781)\end{array}$ & $\begin{array}{l}0,003613 \\
(0,002631)\end{array}$ \\
\hline Perdagangan, Hotel, dan Restoran & $\begin{array}{l}-0,125282 \\
(0,678703)\end{array}$ & $\begin{array}{l}0,027331 \\
(0,020890)\end{array}$ \\
\hline Pengangkutan dan Komunikasi & $\begin{array}{l}0,566278 * * * \\
(0,036962)\end{array}$ & $\begin{array}{l}0,004235^{* * *} \\
(0,001074)\end{array}$ \\
\hline Keuangan, Persewaan, dan Jasa Perusahaan & $\begin{array}{l}-0,104850 * * * \\
(0,020724)\end{array}$ & $\begin{array}{l}0,008667 * * * \\
(0,000847)\end{array}$ \\
\hline Jasa-jasa & $\begin{array}{l}-1,309067 \\
(2,506019)\end{array}$ & $\begin{array}{l}-0,144618 \\
(0,204283)\end{array}$ \\
\hline Adjusted $\mathrm{R}^{2}$ & 0,990207 & \\
\hline F-statistic & $435,4306 * * *$ & \\
\hline DW-statistic & 2,485919 & \\
\hline
\end{tabular}

share sektoral dengan baik. Hal ini didukung pula dengan nilai F-statistik sebesar 601,19 yang menunjukkan signifikansi model tersebut. DW-statistik yang sebesar 2,35 juga menunjukkan model tersebut terhindar dari permasalahan autokorelasi. 
Untuk melihat lebih jauh pengaruh kedua variabel tersebut pada masing-masing sektor usaha, dilakukan regresi dengan cross-section specific coefficient, sebagaimana ditunjukkan pada tabel di atas. Share GDP riil sektoral berpengaruh positif terhadap employment share di sektor pertanian; listrik, gas, dan air bersih; bangunan; serta pengangkutan dan komunikasi. Pengaruh positif ini menunjukkan bahwa sektor-sektor usaha tersebut menyerap tenaga kerja dari sektor-sektor usaha yang share GDP riilnya turun atau sebaliknya dapat dengan mudah kehilangan tenaga kerjanya yang pindah ke sektor usaha lainnya sejalan dengan naik/turunnya share GDP riil sektor usaha yang bersangkutan. Pada periode observasi share GDP riil sektor pertanian mengalami penurunan dari 16,77\% pada tahun 1993 menjadi 14,15\% pada tahun 2006, yang diikuti dengan penurunan employment share sektoralnya dari 50,60\% pada tahun 1993 menjadi 42,05\% pada tahun 2006.

Di sisi lain pengaruhnya justru negatif pada sektor penggalian dan pertambangan; industri pengolahan; perdagangan, hotel, dan restoran; keuangan, persewaan, dan jasa perusahaan; serta sektor jasa-jasa. Hal ini menunjukkan bahwa sektor-sektor usaha tersebut tidak mudah menyerap tenaga kerja dari sektor-sektor usaha lain seiring dengan meningkatnya share GDP riilnya, atau sebaliknya tidak mudah kehilangan tenaga kerjanya pada saat share GDP riilnya menurun. Hal ini sejalan dengan Poloz (1994), yang menyebutkan bahwa pengangguran terjadi karena adanya pergeseran permintaan tenaga kerja inter-sektoral dan proses realokasi tenaga kerja antar sektor usaha yang lambat. Pada periode observasi share GDP riil sektor industri pengolahan meningkat dari 23,46\% pada tahun 1993 menjadi 27,84\% pada tahun 2006 . Meskipun jika dibandingkan dengan tahun 1993 employment share sektor industri pengolahan pada tahun 2006 mengalami peningkatan, yakni menjadi 12,46\% dari semula 11,09\%, terjadi beberapa kali penurunan tajam atas employment share sektoral akibat krisis ekonomi pada tahun 1997 - 1998 dan ketatnya likuiditas perekonomian pada tahun 2002.

Structural unemployment disebabkan sektor-sektor usaha yang ketika share GDP riilnya meningkat justru berdampak negatif terhadap employment share sektoralnya (seperti halnya yang terjadi pada sektor industri pengolahan), dan disebabkan pula oleh sektor-sektor usaha yang pengaruh perubahan share GDP riilnya terhadap employment share sektoralnya positif, yaitu pada saat sektor-sektor usaha tersebut mengalami penurunan share GDP riil, di mana tenaga kerja sektor usaha tersebut tidak mudah mendapatkan pekerjaan di sektor usaha lainnya (seperti halnya yang terjadi pada sektor pertanian).

Beberapa faktor yang melatarbelakangi adanya perbedaan respon sektoral terhadap naik/ turunnya share GDP riil terhadap employment share di masing-masing sektor usaha antara lain: kemampuan/keahlian tenaga kerja sektoral, produktivitas tenaga kerja sektoral, dan perbedaan tingkat upah sektoral. 
Perubahan demand dan supply tenaga kerja di labor market akibat adanya perubahan struktur perekonomian tersebut diyakini mengakibatkan terjadinya pengangguran, mengingat adanya mismatch dalam hal kemampuan/keahlian tenaga kerja yang tersedia di pasar dan yang dibutuhkan oleh perusahaan sejalan dengan perkembangan sektor-sektor usaha tertentu. Akibatnya, banyak tenaga kerja yang tidak dapat diserap. Sementara itu bagi tenaga kerja, perlu waktu untuk mengembangkan kemampuan/keahlian yang dibutuhkan oleh perusahaanperusahaan di sektor usaha yang sedang berkembang. Structural unemployment tidak hanya terjadi ketika sektor-sektor usaha yang berkembang adalah sektor-sektor usaha yang membutuhkan kemampuan/keahlian khusus atau tinggi, seperti pada sektor industri pengolahan. Pada saat sektor-sektor usaha yang berkembang justru adalah sektor-sektor usaha yang membutuhkan tingkat kemampuan/keahlian yang lebih rendah, adakalanya terdapat keengganan dari tenaga kerja untuk melakukan jenis pekerjaan tersebut. Di sisi lain keengganan dari tenaga kerja untuk mempelajari hal-hal baru, misalnya mengingat kendala usia dan biaya yang dibutuhkan, juga menjadi penyebab structural unemployment tersebut. Sebagaimana halnya disebutkan Jovanovic dan Moffitt (1990) serta Thomas (1996), tenaga kerja cenderung berpindah dalam sektor usaha yang sama. Hal tersebut juga terkait dengan tingginya tingkat upah tenaga kerja yang berpengalaman di suatu sektor usaha, sebagaimana disebutkan Helwege (1992).

Untuk mengetahui secara tepat faktor-faktor yang menyebabkan terjadinya structural unemployment di Indonesia dan dinamikanya, dilakukan melalui regresi atas model produktivitas tenaga kerja sektoral, model upah riil tenaga kerja sektoral, dan model structural unemployment, yang akan diuraikan pada bagian berikutnya.

Sementara itu pada umumnya pertumbuhan GDP riil sektoral berdampak positif terhadap employment share sektor-sektor usaha tersebut. Namun pada beberapa sektor usaha terlihat pengaruhnya justru negatif, yakni pada sektor pertanian; penggalian dan pertambangan; serta jasa-jasa. Beberapa hal bisa menjadi penyebabnya. Sektor pertanian kurang menarik bagi pelaku ekonomi sehingga employer dan tenaga kerja beralih ke sektor usaha lainnya (hal ini ditunjukkan dengan pertumbuhan sektor pertanian yang relatif rendah selama periode analisis, rata-rata hanya sekitar 2,30\% per tahun). Pertumbuhan sektor pertanian tersebut diperkirakan lebih disebabkan oleh peningkatan produktivitasnya sehingga tidak memerlukan penambahan tenaga kerja. Pada sektor penggalian dan pertambangan yang terjadi adalah adanya penggunaan mesin dan peralatan sebagai penggerak pertumbuhannya, mengingat sektor usaha tersebut bersifat capital intensive. Sedangkan peningkatan pertumbuhan sektor jasa-jasa yang justru berdampak negatif terhadap employment share sektor usaha tersebut menunjukkan bahwa peningkatan dilakukan pada sisi kualitatif sumber dayanya, bukan dari sisi jumlah tenaga kerjanya. 
Dari hasil regresi employment share sektoral terhadap variabel share GDP riil sektoral dan pertumbuhan GDP riil sektoral, dapat disimpulkan bahwa unemployment di Indonesia pada periode analisis lebih merupakan structural unemployment daripada cyclical unemployment. Hal ini terlihat dari besaran koefisien share GDP riil pada sektor industri pengolahan yang bertanda negatif (menunjukkan bahwa peningkatan share-nya justru menimbulkan pengangguran) dan besaran koefisien share GDP riil pada sektor pertanian yang bertanda positif (menunjukkan bahwa penurunan share-nya akan berdampak pada peningkatan pengangguran), serta dari besaran koefisien variabel pertumbuhan GDP riil sektoral yang bertanda positif (di mana pertumbuhan ekonomi akan meningkatkan employment share sektoral atau mengurangi jumlah pengangguran).

\section{IV.2. Produktivitas Tenaga Kerja Sektoral}

Berdasarkan pengujian dengan F-test dan Hausman test atas model $\Omega_{i, t}=\beta+\delta s_{i, t}+\omega$ $E d_{i, t}+e_{i, t^{\prime}}$ dipilih untuk menggunakan fixed effect model. Nilai adjusted $R$-squared, F-statistik, dan DW-statistik pada hasil regresi tersebut menunjukkan bahwa model tersebut secara keseluruhan bagus.

Hasil regresi, sebagaimana ditunjukkan pada tabel di atas, memperlihatkan bahwa baik share GDP riil sektoral maupun tingkat pendidikan tenaga kerja sektoral berpengaruh positif terhadap produktivitas tenaga kerja sektoral. Hal ini bisa dimengerti mengingat peningkatan share GDP riil, yang pada umumnya disertai dengan peningkatan volume usaha sektoral, akan menyebabkan peningkatan nilai output per pekerja. Sementara itu tingkat pendidikan pekerja sudah tentu menyumbangkan peran yang tidak sedikit bagi peningkatan produktivitas tenaga kerja di masing-masing sektor usaha.

Pengaruh kedua variabel tersebut terhadap produktivitas tenaga kerja di masing-masing sektor usaha dapat diketahui melalui regresi dengan cross-section specific coefficient, sebagaimana hasilnya ditunjukkan pada tabel di atas. Terlihat bahwa pada umumnya tingkat pendidikan tenaga kerja dan share GDP riil sektoral berpengaruh positif terhadap produktivitas tenaga kerja sektoral. Pengaruh positif share GDP riil sektoral tersebut merupakan akibat dari naiknya value added ketika share GDP riil suatu sektor usaha naik. Lundberg (1972) menunjukkan bahwa di samping karena naiknya value added, peningkatan produktivitas tersebut juga terkait dengan naiknya profit.

Namun pada sektor pertanian, industri pengolahan, dan jasa-jasa, share GDP riil sektoral justru berdampak negatif terhadap produktivitas tenaga kerja sektoral. Pada sektor pertanian dan jasa-jasa, penurunan share GDP riil yang disertai dengan penurunan employment share 


\begin{tabular}{|c|c|c|}
\hline \multicolumn{3}{|c|}{$\begin{array}{c}\text { Tabel II.2 } \\
\text { roduktivitas Tenaga Kerja Sektoral }\end{array}$} \\
\hline \multicolumn{3}{|c|}{$\begin{array}{c}\text { Dependent Variable: Produktivitas Tenaga Kerja Sektoral } \\
\text { Periode observasi: } 1993-2006 \\
\text { Metode: Fixed Effect }\end{array}$} \\
\hline \multirow[b]{2}{*}{ Sektor Usaha } & \multicolumn{2}{|c|}{ Explanatory Variables } \\
\hline & $\begin{array}{l}\text { Share GDP Riil } \\
\text { Sektoral } \\
\text { (SHAREGDP) }\end{array}$ & $\begin{array}{l}\text { Tingkat Pendidikan } \\
\text { Tenaga Kerja Sektoral } \\
\text { (EDU) }\end{array}$ \\
\hline \multicolumn{3}{|c|}{ Model I: Common Coefficient } \\
\hline Sektor-sektor Usaha & $\begin{array}{l}1,525616 * * * \\
(0,061824)\end{array}$ & $\begin{array}{l}0,393379 * * * \\
(0,058209)\end{array}$ \\
\hline $\begin{array}{l}\text { Adjusted } R^{2} \\
\text { F-statistic } \\
\text { DW-statistic }\end{array}$ & $\begin{array}{l}0,964552 \\
287,9464 * * * \\
2,085509\end{array}$ & \\
\hline \multicolumn{3}{|c|}{ Model II: Cross-Section Specific Coefficient } \\
\hline Pertanian & $\begin{array}{l}-0,346284^{* * *} \\
(0,001790)\end{array}$ & $\begin{array}{l}0,075178 * * * \\
(0,001301)\end{array}$ \\
\hline Penggalian dan Pertambangan & $\begin{array}{l}27,16095^{\star} \\
(14,75307)\end{array}$ & $\begin{array}{l}5,081117 \\
(5,626744)\end{array}$ \\
\hline Industri Pengolahan & $\begin{array}{l}-2,550514 * * * \\
(0,353650)\end{array}$ & $\begin{array}{l}2,454508 * * * \\
(0,146253)\end{array}$ \\
\hline Listrik, Gas, dan Air Bersih & $\begin{array}{l}54,45820 * * \\
(21,48169)\end{array}$ & $\begin{array}{l}2,325992 * * * \\
(0,803465)\end{array}$ \\
\hline Bangunan & $\begin{array}{l}3,664917 * * * \\
(0,035442)\end{array}$ & $\begin{array}{l}0,236208 * * * \\
(0,020923)\end{array}$ \\
\hline Perdagangan, Hotel, dan Restoran & $\begin{array}{l}3,377875^{* * *} \\
(0,061505)\end{array}$ & $\begin{array}{l}0,192753 * * * \\
(0,004650)\end{array}$ \\
\hline Pengangkutan dan Komunikasi & $\begin{array}{l}4,462313 * * * \\
(0,023957)\end{array}$ & $\begin{array}{l}-0,655985^{* * *} \\
(0,008480)\end{array}$ \\
\hline Keuangan, Persewaan, dan Jasa Perusahaan & $\begin{array}{l}27,44206 \\
(21,17812)\end{array}$ & $\begin{array}{l}-7,005048 \\
(6,421887)\end{array}$ \\
\hline Jasa-jasa & $\begin{array}{l}-0,490531 * * * \\
(0,131701)\end{array}$ & $\begin{array}{l}0,695944 * * * \\
(0,016635)\end{array}$ \\
\hline Adjusted $R^{2}$ & 0,987095 & \\
\hline F-statistic & $329,6274 * * *$ & \\
\hline DW-statistic & 2,112079 & \\
\hline
\end{tabular}

sektoralnya yang lebih besar menyebabkan naiknya produktivitas tenaga kerja di kedua sektor usaha tersebut. Pada sektor pertanian produktivitas tenaga kerja naik dari Rp 4,82 juta pada tahun 1993 menjadi Rp 6,51 juta pada tahun 2006, sedangkan pada sektor jasa-jasa naik dari Rp 10,77 juta pada tahun 1993 menjadi Rp 15,02 juta pada tahun 2006. Sementara itu pada 
sektor industri pengolahan, kenaikan share GDP riil diikuti dengan penurunan produktivitas tenaga kerjanya (akibat naiknya employment share sektoral yang lebih besar) pada sekitar tahun 1999 - 2002. Di sisi lain gejala deindustrialisasi yang ditandai dengan pelambatan pertumbuhan bahkan penurunan share GDP riil sektor industri pengolahan pada tahun 2004 2006, yang diikuti dengan penurunan-employment share sektoral pada tahun 2003, menyebabkan naiknya produktivitas tenaga kerja di sektor industri pengolahan tersebut. Namun secara keseluruhan terjadi peningkatan produktivitas tenaga kerja sektor industri pengolahan, dari Rp 30,75 juta pada tahun 1993 menjadi Rp 43,25 juta pada tahun 2006.

Yang menarik untuk dicermati adalah adanya hubungan positif antara kenaikan produkvitas tenaga kerja sektoral dan'share GDP riil sektoral. Hubungan positif tersebut menunjukkan bahwa sektor-sektor usaha yang share-nya meningkat cenderung untuk tidak menambah jumlah tenaga kerjanya sebesar kenaikan'share GDP riil sektoralnya. Pelaku bisnis akan memanfaatkan momentum perkembangan usahanya untuk meningkatkan produktivitas tenaga kerja dan dengan demikian profitabilitasnya. Hal ini tentunya akan meningkatkan produktivitas tenaga kerja sektor usaha tersebut.

\section{IV.3. Upah Riil Tenaga Kerja Sektoral}

Berdasarkan pengujian dengan F-test dan Hausman test atas model $w_{i, t}=\phi+\sigma s_{i, t}+\bar{w}_{t}+e_{i, t^{\prime}}$ dipilih untuk menggunakan fixed effect model. Pada model ini pun nilai adjusted $R$-squared, Fstatistik, dan DW-statistiknya menunjukkan bahwa model tersebut secara keseluruhan bagus.

Sebagaimana ditunjukkan pada tabel berikut ini, baik share GDP riil sektoral maupun upah riil rata-rata berpengaruh positif terhadap upah riil tenaga kerja di suatu sektor usaha. Hal ini menunjukkan bahwa naik turunnya upah riil di suatu sektor usaha sangat ditentukan oleh naik turunnya upah riil rata-rata. Perusahaan akan menjaga agar tingkat upah riilnya bergerak mengikuti tingkat upah riil rata-rata agar tingkat upah tersebut tetap kompetitif sehingga dapat menjaga tenaga kerjanya agar tidak pindah ke perusahaan lain.

Sementara itu pengaruh positif share GDP riil sektoral terhadap upah riil tenaga kerja sektoral menunjukkan bahwa peningkatan share GDP riil suatu sektor usaha akan mendorong sektor usaha tersebut dapat memberikan upah riil yang lebih tinggi kepada tenaga kerjanya. Demikian pula sebaliknya, semakin kecil share GDP riil suatu sektor usaha, semakin rendah pula upah riil yang dapat dibayarkan kepada tenaga kerjanya. Sebagaimana diketahui, peningkatan share GDP riil sektoral tersebut menunjukkan adanya peningkatan nilai tambah. Hal ini sejalan dengan Behrman (1971), yang memodelkan upah sektoral antara lain sebagai fungsi dari tingkat perubahan rata-rata nilai tambah per tenaga kerja pada suatu sektor 
usaha. Helwege (1992) juga menyebutkan bahwa pekerja dibayar sesuai dengan marginal value produk sehingga upah akan bervariasi sesuai dengan harga dari produk akhir suatu sektor usaha.

\begin{tabular}{|c|c|c|}
\hline \multicolumn{3}{|c|}{$\begin{array}{c}\text { Tabel II.3 } \\
\text { Upah Ritl Tenaga Kerja Sektoral }\end{array}$} \\
\hline \multicolumn{3}{|c|}{$\begin{array}{c}\text { Dependent Variable: Upah Riil Tenaga Kerja Sektoral } \\
\text { Periode observasi: } 1993-2006 \\
\text { Metode: Fixed Effect }\end{array}$} \\
\hline \multirow[b]{2}{*}{ Sektor Usaha } & \multicolumn{2}{|c|}{ Explanatory Variables } \\
\hline & $\begin{array}{l}\text { Share GDP Riil } \\
\text { Sektoral } \\
\text { (SHAREGDP) }\end{array}$ & $\begin{array}{c}\text { Upah Riil Tenaga Kerja } \\
\text { Rata-rata } \\
\text { (UPAHRATA) }\end{array}$ \\
\hline \multicolumn{3}{|c|}{ Model I: Common Coefficient } \\
\hline Sektor-sektor Usaha & $\begin{array}{l}0.135752 * * * \\
(0.062627)\end{array}$ & $\begin{array}{l}0.190481 * * * \\
(0.033805)\end{array}$ \\
\hline Adjusted $\mathrm{R}^{2}$ & 0.850326 & \\
\hline F-statistic & $60.91058 * * *$ & \\
\hline DW-statistic & 1.801097 & \\
\hline \multicolumn{3}{|c|}{ Model II: Cross-Section Specific Coefficient } \\
\hline Pertanian & $\begin{array}{l}0,147741 * * * \\
(0,02941)\end{array}$ & $\begin{array}{l}0,019125 \\
(0,012492)\end{array}$ \\
\hline Penggalian dan Pertambangan & $\begin{array}{l}-0,146193 \\
(0,369895)\end{array}$ & $\begin{array}{l}0,348597 * \\
(0,175596)\end{array}$ \\
\hline Industri Pengolahan & $\begin{array}{l}0,175185 \\
(0,228803)\end{array}$ & $\begin{array}{l}0,540866 * * \\
(0,258901)\end{array}$ \\
\hline Listrik, Gas, dan Air Bersih & $\begin{array}{l}8,301964 \\
(5,808157)\end{array}$ & $\begin{array}{l}0,297153 \\
(0,670220)\end{array}$ \\
\hline Bangunan & $\begin{array}{l}0,182121 \\
(0,170255)\end{array}$ & $\begin{array}{l}0,297184 * * * \\
(0,086456)\end{array}$ \\
\hline Perdagangan, Hotel, dan Restoran & $\begin{array}{l}0,823759 * * * \\
(0,291064)\end{array}$ & $\begin{array}{l}0,541314 * * * \\
(0,085994)\end{array}$ \\
\hline Pengangkutan dan Komunikasi & $\begin{array}{l}0,976051 * * * \\
(0,251687)\end{array}$ & $\begin{array}{l}0,156008 \\
(0,116085)\end{array}$ \\
\hline Keuangan, Persewaan, dan Jasa Perusahaan & $\begin{array}{l}0,937289 \\
(0,704827)\end{array}$ & $\begin{array}{l}0,953288 * * \\
(0,432890)\end{array}$ \\
\hline Jasa-jasa & $\begin{array}{l}-0,280346 \\
(4,479822)\end{array}$ & $\begin{array}{l}0,683282 \\
(0,890563)\end{array}$ \\
\hline Adjusted $\mathrm{R}^{2}$ & 0,901705 & \\
\hline F-statistic & $40,41180 * * *$ & \\
\hline DW-statistic & 1,885108 & \\
\hline
\end{tabular}


Untuk mendapatkan gambaran yang lebih detail, dilakukan regresi dengan dengan crosssection specific coefficient, sebagaimana hasilnya ditunjukkan pada tabel di atas. Terlihat bahwa peningkatan upah riil rata-rata akan meningkatkan upah riil suatu sektor usaha. Sementara itu peningkatan share GDP riil sektoral akan meningkatkan upah riil pada sebagian besar sektor usaha, kecuali sektor penggalian dan pertambangan serta jasa-jasa. Penurunan share GDP riil sektor pertanian berdampak pada penurunan upah riilnya, sementara sektor-sektor usaha yang berkembang akan meningkat pula upah riilnya. Sedangkan pada sektor penggalian dan pertambangan serta jasa-jasa penurunan share GDP riil sektoral diikuti dengan peningkatan upah riilnya.

Sepanjang tahun 1993 - 2006 terlihat bahwa upah riil tenaga kerja sektor pertanian berada pada level yang sangat rendah dan cenderung konstan, yakni rata-ratanya sekitar Rp 2,98 juta. Diperkirakan upah riil sektor pertanian naik seiring dengan naiknya upah riil ratarata, namun diikuti dengan turunnya upah riil sektor tersebut seiring dengan semakin kecil share GDP riil sektoralnya. Upah riil rata-rata selama periode obsevasi adalah sebesar Rp 5,94 juta. Di sisi lain upah riil sektor-sektor usaha lainnya terlihat mengalami peningkatan yang berarti. Hal tersebut tentunya menimbulkan gap yang semakin lebar antara upah riil sektor pertanian (yang memiliki employment share terbesar) dan upah riil sektor-sektor usaha lainnya. Perbedaan upah riil antar sektor usaha tersebut dapat memicu timbulnya structural unemployment.

\section{IV.4. Structural Unemployment}

Pengujian hasil regresi model $E_{i, t}=\alpha+\gamma \Omega_{i, t}+\lambda w_{i, t}+\eta y_{i, t}+e_{i, t}$ dengan F-test dan Hausman test menunjukkan bahwa fixed effect model lebih dipilih untuk digunakan. Pada model ini pun nilai adjusted $R$-squared, F-statistik, dan DW-statistiknya menunjukkan bahwa model tersebut secara keseluruhan bagus.

Sebagaimana ditunjukkan pada tabel berikut ini, hasil regresi dengan common coefficient menunjukkan bahwa pengaruh produktivitas tenaga kerja sektoral terhadap employment share sektoral adalah negatif. Hal ini berarti semakin besar produktivitas tenaga kerja suatu sektor usaha, employer akan terus menjaga dan bahkan meningkatkannya, sehingga tidak melakukan rekrutmen tenaga kerja baru selama peningkatan produktivitas tenaga kerja tersebut belum mencapati titik optimalnya, kecuali untuk tenaga kerja dengan keahlian tertentu. Dengan jumlah tenaga kerja yang relatif tidak berubah, seiring dengan pertambahan jumlah tenaga kerja secara nasional, maka employment share sektor usaha tersebut akan turun. Jadi peningkatan produktivitas tenaga kerja pada suatu sektor usaha akan diikuti dengan penurunan employment share-nya. 
Sementara itu koefisien variabel upah riil tenaga kerja sektoral yang bertanda positif menunjukkan bahwa semakin tinggi tingkat upah riil di suatu sektor usaha, semakin tinggi pula employment share-nya. Hal ini menunjukkan adanya daya tarik dari sisi supply tenaga kerja, dan di sisi lain menunjukkan bahwa sisi demand tenaga kerja dapat mengakomodasiya, yang bisa jadi terkait dengan pertimbangan peningkatan produktivitas dan efficiency wage.

Besaran koefisien variabel pertumbuhan GDP riil sektoral bertanda positif, menunjukkan bahwa pertumbuhan GDP riil suatu sektor usaha akan mendorong penyerapan tenaga kerja di sektor usaha yang tumbuh tersebut, demikian pula sebaliknya.

Untuk melihat lebih jauh tentang perilaku masing-masing sektor usaha, dilakukan regresi dengan cross-section specific coefficient, sebagaimana hasilnya ditunjukkan pada tabel berikut ini. Terlihat bahwa sebagian besar sektor usaha mengikuti pola sebagaimana hasil regresi dengan common coefficient seperti disebutkan di atas. Hanya sektor penggalian dan pertambangan serta jasa-jasa yang menunjukkan respon yang berbeda pada sebagian variabelnya. Hasil regresi tersebut sejalan dengan Blien dan Sanner (2006) yang menunjukkan adanya hubungan antara produktivitas tenaga kerja sektoral dan pengangguran, juga Reder (1964), yang menyebutkan adanya hubungan antara struktur upah dan pengangguran.

Pada periode observasi produktivitas tenaga kerja sektor pertanian naik dari Rp 4,82 juta pada tahun 1993 menjadi Rp 6,51 juta pada tahun 2006. Naiknya produktivitas tenaga kerja sektor pertanian tersebut berdampak pada turunnya employment share sektor pertanian. Sementara itu upah riil tenaga kerja sektor pertanian berada pada level yang sangat rendah dan cenderung konstan, yakni rata-ratanya sekitar Rp 2,98 juta. Pertumbuhan sektor pertanian juga relatif rendah, yakni rata-ratanya hanya sekitar 2,30\% per tahun. Rendahnya upah riil dan pertumbuhan sektor pertanian dibandingkan sektor-sektor usaha lainnya juga menyebabkan turunnya employment share sektor pertanian, yang berdampak pada pengangguran.

Sementara itu produktivitas tenaga kerja sektor industri pengolahan naik dari Rp 30,75 juta pada tahun 1993 menjadi Rp 43,25 juta pada tahun 2006. Upah riil tenaga kerja sektor industri pengolahan cukup tinggi, yakni rata-ratanya sebesar Rp 6,04 juta. Pertumbuhan sektor industri pengolahan pun relatif tinggi, yakni rata-ratanya sebesar 5,53\% per tahun. Naiknya produktivitas tenaga kerja sektor industri pengolahan tersebut berdampak pada turunnya employment share sektor tersebut, namun di sisi lain tingginya upah riil dan pertumbuhan sektor tersebut berdampak pada naiknya employment share-nya.

Dari hasil regresi tersebut dapat disimpulkan bahwa pengangguran yang terjadi di Indonesia saat ini bukan merupakan cyclical unemployment, mengingat pada saat pertumbuhan 


\begin{tabular}{|c|c|c|c|}
\hline \multicolumn{4}{|c|}{$\begin{array}{l}\text { Tabel II.4 } \\
\text { Iral Unemployment }\end{array}$} \\
\hline \multicolumn{4}{|c|}{$\begin{array}{c}\text { Dependent Variable: Employment Share Sektoral } \\
\text { Periode observasi: } 1993 \text { - } 2006 \\
\text { Metode: Fixed Effect }\end{array}$} \\
\hline \multirow[b]{2}{*}{ Sektor Usaha } & \multicolumn{3}{|c|}{ Explanatory Variables } \\
\hline & $\begin{array}{l}\text { Produktivitas } \\
\text { Tenaga Kerja } \\
\text { Sektoral } \\
\text { (PRODUKTVS) }\end{array}$ & $\begin{array}{l}\text { Upah Riil Tenaga } \\
\text { Kerja Sektoral } \\
\text { (UPAHRIIL) }\end{array}$ & $\begin{array}{l}\text { Pertumbuhan GDP } \\
\text { Riil Sektoral } \\
\text { (GDPGROWTH) }\end{array}$ \\
\hline \multicolumn{4}{|c|}{ Model I: Common Coefficient } \\
\hline Sektor-sektor Usaha & $\begin{array}{l}-0,003969 * * * \\
(2,51 \mathrm{E}-05)\end{array}$ & $\begin{array}{l}0,010604^{* * *} \\
(0,000712)\end{array}$ & $\begin{array}{l}0,003605 * * * \\
(0,000288)\end{array}$ \\
\hline Adjusted $\mathrm{R}^{2}$ & \multicolumn{3}{|l|}{0,974719} \\
\hline F-statistic & \multicolumn{3}{|l|}{$373,7034^{* * *}$} \\
\hline DW-statistic & \multicolumn{3}{|l|}{2,352236} \\
\hline \multicolumn{4}{|c|}{ Model II: Cross-Section Specific Coefficient } \\
\hline Pertanian & $\begin{array}{l}-4,066669 \\
(2,633352)\end{array}$ & $\begin{array}{l}1,947548 \\
(3,821177)\end{array}$ & $\begin{array}{l}0,366157 \\
(0,638210)\end{array}$ \\
\hline Penggalian dan Pertambangan & $\begin{array}{l}-0,003883 * * * \\
(2,11 \mathrm{E}-05)\end{array}$ & $\begin{array}{l}-0,013009 * * * \\
(0,000835)\end{array}$ & $\begin{array}{l}-0,000378 \\
(0,000393)\end{array}$ \\
\hline Industri Pengolahan & $\begin{array}{l}-0,237612 * * * \\
(0,010267)\end{array}$ & $\begin{array}{l}0,530601 * * * \\
(0,032842)\end{array}$ & $\begin{array}{l}0,100118 * * * \\
(0,005518)\end{array}$ \\
\hline Listrik, Gas, dan Air Bersih & $\begin{array}{l}-0,003406^{* * *} \\
(7,49 \mathrm{E}-05)\end{array}$ & $\begin{array}{l}0,012603 * * * \\
(0,000445)\end{array}$ & $\begin{array}{l}0,002664 * * * \\
(0,000162)\end{array}$ \\
\hline Bangunan & $\begin{array}{l}-0,024462 \\
(0,016067)\end{array}$ & $\begin{array}{l}0,454229 * * * \\
(0,064767)\end{array}$ & $\begin{array}{l}0,025669 * * * \\
(0,002529)\end{array}$ \\
\hline Perdagangan, Hotel, dan Restoran & $\begin{array}{l}-0,712559 * * * \\
(0,139394)\end{array}$ & $\begin{array}{l}0,752508 * * * \\
(0,205636)\end{array}$ & $\begin{array}{l}0,099226 * * * \\
(0,015822)\end{array}$ \\
\hline Pengangkutan dan Komunikasi & $\begin{array}{l}-0,058129 * * \\
(0,025410)\end{array}$ & $\begin{array}{l}0,343357 * * * \\
(0,058579)\end{array}$ & $\begin{array}{l}0,035070 * * * \\
(0,005241)\end{array}$ \\
\hline Keuangan, Persewaan, dan Jasa Perusahaan & $\begin{array}{l}-0,004252 * * * \\
(0,000168)\end{array}$ & $\begin{array}{l}0,043593 * * * \\
(0,001775)\end{array}$ & $\begin{array}{l}0,008283 * * * \\
(0,000213)\end{array}$ \\
\hline Jasa-jasa & $\begin{array}{l}-0,782335 * * * \\
(0,234048)\end{array}$ & $\begin{array}{l}-0,025060 \\
(0,132794)\end{array}$ & $\begin{array}{l}0,099510 \\
(0,078059)\end{array}$ \\
\hline Adjusted $\mathrm{R}^{2}$ & 0,995361 & & \\
\hline F-statistic & $692,3444 * * *$ & & \\
\hline DW-statistic & 2,290996 & & \\
\hline
\end{tabular}

ekonomi tinggi (meskipun bervariasi antar sektor usaha) seharusnya tingkat employment juga tinggi. Rendahnya tingkat employment (atau tingginya tingkat pengangguran) saat ini lebih disebabkan oleh faktor-faktor struktural sebagai berikut: 
a) Produktivitas Tenaga Kerja Sektoral

Jika dicermati lebih jauh, structural unemployment tidak hanya terkait dengan persyaratan atas kemampuan/keahlian tenaga kerja. Perubahan struktur perekonomian diperkirakan akan mempengaruhi produktivitas tenaga kerja. Beberapa sektor usaha yang share-nya mengecil, jika tidak disertai dengan pengurangan tenaga kerja, akan berakibat turunnya produktivitas tenaga kerja, dan tentunya profitabilitas di sektor usaha yang bersangkutan. Hal ini akan memicu perusahaan-perusahaan di sektor usaha tersebut untuk mengurangi jumlah tenaga kerjanya guna mempertahankan tingkat produktivitas tenaga kerja dan profitabilitasnya.

Sementara itu bagi sektor-sektor usaha yang share-nya membesar tidak secara otomatis akan menyerap tenaga kerja dari sektor-sektor usaha yang share-nya mengecil. Perusahaan akan berusaha mempertahankan jumlah tenaga kerjanya sehingga produktivitas tenaga kerja akan meningkat. Perusahaan-perusahaan tersebut akan memanfaatkan momentum perkembangan bisnisnya untuk meningkatkan produktivitas tenaga kerjanya. Dengan kata lain, perusahaan tidak akan segera melakukan rekrutmen tenaga kerja meskipun usahanya semakin berkembang. Penambahan tenaga kerja hanya dilakukan ketika produktivitas tenaga kerja sudah menjadi sedemikian tinggi sehingga penambahan beban kerja akan menyebabkan turunnya produktivitas tenaga kerja yang bersangkutan (yakni ketika $M P_{L}=0$ ), atau pun hanya dilakukan jika benar-benar diperlukan, misalnya untuk posisi-posisi yang memerlukan kemampuan/keahlian khusus.

b) Upah Riil Tenaga Kerja Sektoral

Faktor lain yang menyebabkan timbulnya structural unemployment tersebut adalah upah riil tenaga kerja sektoral. Sebagaimana diketahui, terdapat perbedaan besaran upah riil antar sektor usaha. Beberapa sektor usaha, seperti penggalian dan pertambangan; listrik, gas, dan air bersih; keuangan, persewaan, dan jasa perusahaan; serta jasa-jasa, menawarkan tingkat upah riil yang lebih tinggi dibandingkan tingkat upah riil di beberapa sektor usaha lainnya. Sementara itu upah riil sektor pertanian sangat rendah. Besarnya gap antara upah riil sektor pertanian dan sektor-sektor usaha lainnya tersebut tentunya menyebabkan tenaga kerja dari sektor pertanian berpindah ke sektor-sektor usaha lainnya. Namun seringkali terdapat ketidaksesuaian antara upah riil di suatu sektor usaha dan produktivitas tenaga kerja yang berusaha bekerja di sektor usaha tersebut. Tenaga kerja dari sektor pertanian yang produktivitasnya relatif rendah, ketika hendak bekerja di sektor usaha lainnya, tentunya tidak mudah mendapatkan pekerjaan. Sektor usaha yang dituju di samping menawarkan upah riil yang lebih tinggi daripada upah riil di sektor pertanian juga mensyaratkan kemampuan/keahlian 
tertentu dengan tingkat produktivitas yang tinggi, yang hal tersebut tidak dimiliki oleh sebagian besar tenaga kerja yang berasal dari sektor pertanian.

\section{IV.5. Implikasi Kebijakan}

Sebagaimana disebutkan di atas, pengangguran yang terjadi di Indonesia saat ini lebih merupakan structural unemployment daripada cyclical unemployment. Untuk menekan structural unemployment tersebut, diperlukan kebijakan sektoral yang terkoordinasi. Sementara itu untuk menghindari terjadinya structural unemployment pada masa yang akan datang, diperlukan suatu perencanaan ekonomi yang baik, dengan melibatkan semua departemen teknis. Dalam hal ini Bappenas tentunya memegang peranan penting.

Di samping itu dukungan dari sisi kebijakan moneter dan perbankan juga sangat diperlukan. Sebagaimana diketahui kebijakan moneter Bank Indonesia merupakan kebijakan tunggal yang berlaku bagi seluruh sektor usaha. Namun di sisi lain kebijakan moneter tersebut memberikan dampak yang berbeda-beda pada tiap sektor usaha, tergantung pada beberapa hal seperti struktur keuangan perusahaan (financial leverage dan kebutuhan modal kerja), skala usaha, capital intensity, durabilitas produk yang dihasilkan, serta keterkaitan antar sektor usaha, sebagaimana disebutkan Dedola dan Lippi (2000). Adanya asimetri atas dampak kebijakan moneter tersebut tentunya patut dicermati, dan Bank Indonesia perlu memberi perhatian lebih kepada sektor-sektor usaha yang mempunyai employment share besar dalam mendesain kebijakan moneternya. Sementara itu kebijakan perbankan juga dapat diarahkan agar dapat mengawal proses perubahan struktur perekonomian dengan baik, antara lain dengan memberikan kemudahan pembiayaan kepada sektor-sektor usaha yang mengalami kesulitan dalam menghadapi proses perubahan struktur tersebut.

\section{KESIMPULAN DAN REKOMENDASI}

\section{V.1. Kesimpulan}

Dari uraian di atas dapat disimpulkan beberapa hal terkait dengan faktor-faktor yang mempengaruhi structural unemployment dan dinamikanya, yakni sebagai berikut:

1. Beberapa faktor yang melatarbelakangi adanya perbedaan respon sektoral terhadap naik/ turunnya share GDP riil terhadap employment share di masing-masing sektor usaha antara lain: kemampuan/keahlian tenaga kerja sektoral, produktivitas tenaga kerja sektoral, dan perbedaan tingkat upah sektoral. 
2. Dari hasil regresi employment share sektoral terhadap variabel share GDP riil sektoral dan pertumbuhan GDP riil sektoral, dapat disimpulkan bahwa unemployment di Indonesia pada periode analisis lebih merupakan structural unemployment daripada cyclical unemployment. Hal ini terlihat dari beberapa hal sebagai berikut:

a. Besaran koefisien share GDP riil pada sektor industri pengolahan yang bertanda negatif, yang menunjukkan bahwa peningkatan share-nya justru menimbulkan pengangguran.

b. Besaran koefisien share GDP riil pada sektor pertanian yang bertanda positif, yang menunjukkan bahwa penurunan share-nya akan berdampak pada peningkatan pengangguran.

c. Besaran koefisien variabel pertumbuhan GDP riil sektoral yang bertanda positif, di mana pertumbuhan ekonomi akan meningkatkan employment share sektoral atau mengurangi jumlah pengangguran.

3. Pada umumnya tingkat pendidikan tenaga kerja dan share GDP riil sektoral berpengaruh positif terhadap produktivitas tenaga kerja sektoral. Namun pada sektor pertanian, industri pengolahan, dan jasa-jasa, share GDP riil sektoral justru berdampak negatif terhadap produktivitas tenaga kerja sektoral. Pada sektor pertanian dan jasa-jasa, penurunan share GDP riil yang disertai dengan penurunan employment share sektoralnya yang lebih besar menyebabkan naiknya produktivitas tenaga kerja di kedua sektor usaha tersebut.

4. Hubungan positif antara kenaikan produkvitas tenaga kerja sektoral dan share GDP riil sektoral menunjukkan bahwa sektor-sektor usaha yang share-nya meningkat cenderung untuk tidak menambah jumlah tenaga kerjanya sebesar kenaikan share GDP riil sektoralnya. Pelaku bisnis akan memanfaatkan momentum perkembangan usahanya untuk meningkatkan produktivitas tenaga kerja dan dengan demikian profitabilitasnya. Hal ini tentunya akan meningkatkan produktivitas tenaga kerja sektor usaha tersebut.

5. Baik share GDP riil sektoral maupun upah riil rata-rata berpengaruh positif terhadap upah riil tenaga kerja di suatu sektor usaha. Hal ini menunjukkan bahwa naik turunnya upah riil di suatu sektor usaha sangat ditentukan oleh naik turunnya upah riil rata-rata. Perusahaan akan menjaga agar tingkat upah riilnya bergerak mengikuti tingkat upah riil rata-rata agar tingkat upah tersebut tetap kompetitif sehingga dapat menjaga tenaga kerjanya agar tidak pindah ke perusahaan lain. Sementara itu pengaruh positif share GDP riil sektoral terhadap upah riil tenaga kerja sektoral menunjukkan bahwa peningkatan share GDP riil suatu sektor usaha akan mendorong sektor usaha tersebut dapat memberikan upah riil yang lebih tinggi kepada tenaga kerjanya, demikian pula sebaliknya.

6. Pada regresi model structural unemployment, diperoleh hasil sebagai berikut:

a. Produktivitas tenaga kerja sektoral berpengaruh negatif terhadap employment share sektoral. Hal ini berarti semakin besar produktivitas tenaga kerja suatu sektor usaha, 
employerakan terus menjaga dan bahkan meningkatkannya, sehingga tidak melakukan rekrutmen tenaga kerja baru selama peningkatan produktivitas tenaga kerja tersebut belum mencapati titik optimalnya. Jadi peningkatan produktivitas tenaga kerja pada suatu sektor usaha akan diikuti dengan penurunan employment share-nya.

b. Upah riil tenaga kerja sektoral berpengaruh positif terhadap employment share sektoral. Hal ini menunjukkan bahwa semakin tinggi tingkat upah riil di suatu sektor usaha, semakin tinggi pula employment share-nya. Hal ini menunjukkan adanya daya tarik dari sisi supply tenaga kerja, dan di sisi lain menunjukkan bahwa sisi demand tenaga kerja dapat mengakomodasiya, yang bisa jadi terkait dengan pertimbangan peningkatan produktivitas dan efficiency wage.

c. Pertumbuhan GDP riil sektoral berpengaruh positif employment share sektoral. Hal ini menunjukkan bahwa pertumbuhan GDP riil suatu sektor usaha akan mendorong penyerapan tenaga kerja di sektor usaha yang tumbuh tersebut, demikian pula sebaliknya.

7. Dalam menghadapi structural unemployment tersebut diperlukan kebijakan sektoral yang terkoordinasi, perencanaan ekonomi yang baik, dan dukungan kebijakan moneter dan perbankan.

\section{V.2. Rekomendasi}

Beberapa hal yang bisa disarankan terkait dengan hasil penelitian tersebut antara lain:

1. Perlu dilakukan studi lebih lanjut untuk melakukan simulasi berbagai kebijakan guna mengurangi dampak buruk dari perubahan struktur perekonomian. Dengan demikian diharapkan perubahan struktur perekonomian tersebut tidak menimbulkan terjadinya structural unemployment dalam skala yang relatif besar seperti halnya yang terjadi di Indonesia saat ini.

2. Perlunya dilakukan prediksi perubahan struktur perekonomian pada masa yang akan datang dan disiapkan perencanaan ekonominya termasuk kebutuhan sumber daya manusianya, sehingga dapat ditekan kemungkinan terjadinya pengangguran. 


\section{DAFTAR PUSTAKA}

Behrman, Jere R. "The Determinants of the Annual Rates of Change of Sectoral Money Wages in a Developing Economy." International Economic Review, Oktober 1971, 12(3), 431-447.

Blien, Uwe dan Sanner, Helge. "Structural Change and Regional Employment Dynamics". Diskussionsbeitrag - Universitat Postdam, No. 82, Februari 2006.

Cassino, Vincenzo dan Thornton, Richard. Do Changes in Structural Factors Explain Movements in the Equilibrium Rate of Unemployment? London: Bank of England, 2002.

Dedola, L. dan Lippi, F. "The Monetary Transmission Mechanism: Evidence from the Industries of Five OECD Countries." Temi di Dissussione Banca d'Italia, No. 389, Desember 2000.

Helwege, Jean. "Sectoral Shifts and Interindustry Wage Differentials." Journal of Labor Economics, Januari 1992, 10(1), 55-84.

Jovanovic, Boyan dan Moffitt, Robert. "An Estimate of a Sectoral Model of Labor Mobility." The Journal of Political Economy, Agustus 1990, 98(4), 827-852.

Lee, Kevin C. dan Pesaran, M. Hashem. "The Role of Sectoral Interactions in Wage Determination in the UK Economy." The Economic Journal, Januari 1993, 103(416), 21-55.

Lipsey, Richard G.; Courant, Paul N.; dan Ragan, Christopher T.S. Economics. 12 ${ }^{\text {th }}$ Edition. Massachusetts: Addison-Wesley, 1999.

Lundberg, Erik. "Productivity and Structural Change - A Policy Issue in Sweden." The Economic Journal, Maret 1972, 82(325), 465-485.

Neelin, Janet. "Sectoral Shifts and Canadian Unemployment." The Review of Economics and Statistics, November 1987, 69(4), 718-723.

OECD. Measuring Productivity: Measurement of Aggregate and Industry-Level Productivity Growth. OECD: Paris, 2001.

Poloz, Stephen S. "The Causes of Unemployment in Canada: A Review of the Evidence." Working Paper - Bank of Canada, No. 94-11, November 1994.

Reder, M.W. "Wage Structure and Structural Unemployment." The Review of Economic Studies, Oktober 1964, 31(4), 309-322. 
Riordan, Michael H. dan Staiger, Robert W. "Sectoral Shocks and Structural Unemployment." International Economic Review, Agustus 1993, 34(3), 611-629.

Stoikov, Vladimir. "Increasing Structural Unemployment Re-examined." Industrial and Labor Relations Review, April 1966, 19(3), 368-376.

Thomas, Jonathan M. "An Empirical Model of Sectoral Movements by Unemployed Workers." Journal of Labor Economics, Januari 1996, 14(1), 126-153. 


\section{LAMPIRAN II.A}

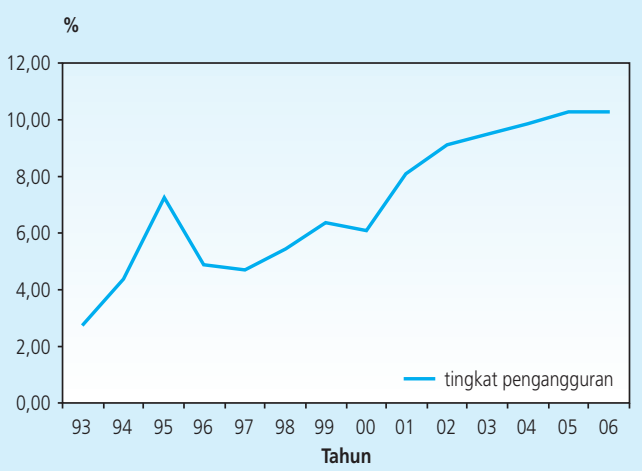

Grafik II.A.1

Tingkat Pengangguran di Indonesia

\section{Tabel II.A.1}

Tingkat Pengangguran di Indonesia

\begin{tabular}{l|c|c}
\multirow{2}{*}{ Periode } & \multicolumn{2}{|c}{ Jumlah/Tingkat Pengangguran } \\
\cline { 2 - 3 } 1993 & Ribuan Orang & $\%$ \\
1994 & 2.246 & 2,76 \\
1995 & 3.738 & 4,36 \\
1996 & 6.251 & 7,24 \\
1997 & 4.408 & 4,89 \\
1998 & 4.275 & 4,68 \\
1999 & 5.062 & 5,46 \\
2000 & 6.030 & 6,36 \\
2001 & 5.813 & 6,08 \\
2002 & 8.005 & 8,10 \\
2003 & 9.132 & 9,10 \\
2004 & 9.531 & 9,50 \\
2005 & 10.251 & 9,86 \\
2006 & 10.854 & 10,26 \\
& 10.875 & 10,28
\end{tabular}




\section{LAMPIRAN II.B}

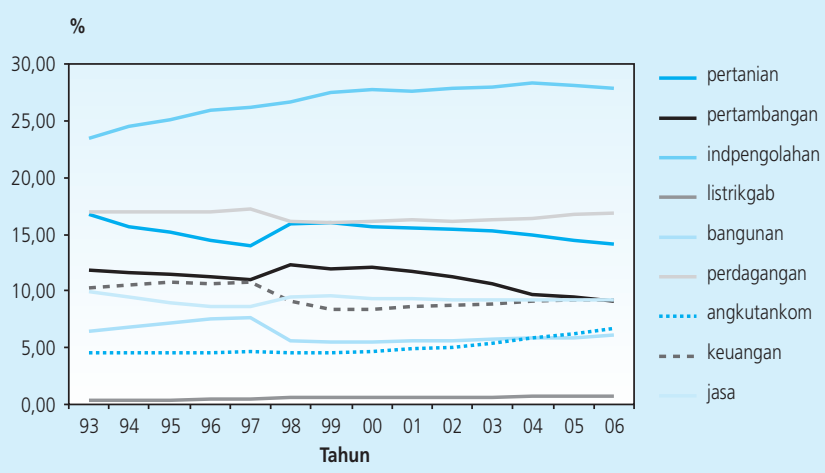

Grafik II.B.1

Share GDP Riil Sektoral (\%)

\begin{tabular}{|c|c|c|c|c|c|c|c|c|c|}
\hline & & & She & $\begin{array}{l}\text { Tabel } \\
\text { re GDP Rit }\end{array}$ & $\begin{array}{l}\text { II.B.1 } \\
\text { Il Sektoral }\end{array}$ & $(\%)$ & & & \\
\hline Periode & Pertanian & $\begin{array}{l}\text { Pengga- } \\
\text { lian \& } \\
\text { Pertam- } \\
\text { bangan }\end{array}$ & $\begin{array}{l}\text { Industri } \\
\text { Peng- } \\
\text { olahan }\end{array}$ & $\begin{array}{l}\text { Listrik, } \\
\text { Gas, \& Air } \\
\text { Bersih }\end{array}$ & Bangunan & $\begin{array}{l}\text { Perda- } \\
\text { gangan, } \\
\text { Hotel \& } \\
\text { Restoran }\end{array}$ & $\begin{array}{l}\text { Peng- } \\
\text { angkutan } \\
\text { \& Komu- } \\
\text { nikasi }\end{array}$ & $\begin{array}{c}\text { Keuangan, } \\
\text { Sewa \& } \\
\text { Jasa } \\
\text { Perush. }\end{array}$ & $\begin{array}{c}\text { Jasa- } \\
\text { jasa }\end{array}$ \\
\hline 1993 & 16,77 & 11,79 & 23,46 & 0,36 & 6,43 & 16,97 & 4,52 & 10,25 & 9,88 \\
\hline 1994 & 15,68 & 11,58 & 24,51 & 0,38 & 6,87 & 16,99 & 4,55 & 10,50 & 9,44 \\
\hline 1995 & 15,12 & 11,42 & 25,12 & 0,41 & 7,17 & 16,94 & 4,56 & 10,77 & 9,01 \\
\hline 1996 & 14,47 & 11,26 & 25,99 & 0,43 & 7,50 & 17,00 & 4,60 & 10,59 & 8,64 \\
\hline 1997 & 13,96 & 10,98 & 26,13 & 0,46 & 7,69 & 17,18 & 4,70 & 10,72 & 8,55 \\
\hline 1998 & 15,85 & 12,29 & 26,64 & 0,55 & 5,62 & 16,17 & 4,59 & 9,05 & 9,46 \\
\hline 1999 & 16,07 & 12,00 & 27,47 & 0,59 & 5,47 & 16,04 & 4,52 & 8,33 & 9,57 \\
\hline 2000 & 15,60 & 12,07 & 27,75 & 0,60 & 5,51 & 16,15 & 4,68 & 8,31 & 9,34 \\
\hline 2001 & 15,54 & 11,68 & 27,65 & 0,63 & 5,56 & 16,20 & 4,88 & 8,56 & 9,30 \\
\hline 2002 & 15,39 & 11,29 & 27,86 & 0,66 & 5,61 & 16,16 & 5,06 & 8,74 & 9,23 \\
\hline 2003 & 15,24 & 10,63 & 28,01 & 0,66 & 5,68 & 16,26 & 5,42 & 8,90 & 9,20 \\
\hline 2004 & 14,92 & 9,66 & 28,37 & 0,66 & 5,82 & 16,37 & 5,85 & 9,12 & 9,23 \\
\hline 2005 & 14,49 & 9,43 & 28,07 & 0,66 & 5,91 & 16,79 & 6,25 & 9,22 & 9,18 \\
\hline 2006 & 14,15 & 9,14 & 27,84 & 0,66 & 6,11 & 16,89 & 6,74 & 9,23 & 9,24 \\
\hline
\end{tabular}




\section{LAMPIRAN II.C}

\begin{tabular}{|c|c|c|c|c|c|c|c|c|c|c|}
\hline & & & Pert & umbuhan & $\begin{array}{l}\text { abel II.C. } \\
\text { GDP Ritl }\end{array}$ & 1 & $(\%)$ & & & \\
\hline Periode & Pertanian & $\begin{array}{l}\text { Pengga- } \\
\text { lian \& } \\
\text { Pertam- } \\
\text { bangan }\end{array}$ & $\begin{array}{l}\text { Industri } \\
\text { Peng- } \\
\text { olahan }\end{array}$ & $\begin{array}{c}\text { Listrik, } \\
\text { Gas, \& Air } \\
\text { Bersih }\end{array}$ & Bangunan & $\begin{array}{l}\text { Perda- } \\
\text { gangan, } \\
\text { Hotel \& } \\
\text { Restoran }\end{array}$ & $\begin{array}{c}\text { Peng- } \\
\text { angkutan } \\
\text { \& Komu- } \\
\text { nikasi }\end{array}$ & $\begin{array}{c}\text { Keuangan, } \\
\text { Sewa \& } \\
\text { Jasa } \\
\text { Perush. }\end{array}$ & $\begin{array}{l}\text { Jasa- } \\
\text { jasa }\end{array}$ & Total \\
\hline 1993 & 1,42 & 2,18 & 9,35 & 4,08 & 12,15 & 8,76 & 9,89 & 10,27 & 4,26 & 6,45 \\
\hline 1994 & 0,56 & 5,60 & 12,36 & 12,54 & 14,86 & 7,61 & 8,34 & 10,17 & 2,77 & 7,54 \\
\hline 1995 & 4,38 & 6,74 & 10,88 & 15,91 & 12,92 & 7,94 & 8,50 & 11,04 & 3,27 & 8,22 \\
\hline 1996 & 3,14 & 6,30 & 11,59 & 13,63 & 12,76 & 8,16 & 8,68 & 6,04 & 3,40 & 7,82 \\
\hline 1997 & 1,00 & 2,12 & 5,25 & 12,37 & 7,36 & 5,83 & 7,01 & 5,93 & 3,62 & 4,70 \\
\hline 1998 & $(1,33)$ & $(2,76)$ & $(11,44)$ & 3,03 & $(36,44)$ & $(18,22)$ & $(15,13)$ & $(26,63)$ & $(3,85)$ & $(13,13)$ \\
\hline 1999 & 2,16 & $(1,62)$ & 3,92 & 8,27 & $(1,91)$ & $(0,06)$ & $(0,75)$ & $(7,19)$ & 1,94 & 0,79 \\
\hline 2000 & 1,88 & 5,51 & 5,98 & 7,56 & 5,64 & 5,67 & 8,59 & 4,59 & 2,33 & 4,92 \\
\hline 2001 & 3,26 & 0,33 & 3,30 & 7,92 & 4,58 & 3,95 & 8,10 & 6,76 & 3,24 & 3,64 \\
\hline 2002 & 3,45 & 1,00 & 5,29 & 8,94 & 5,48 & 4,27 & 8,39 & 6,70 & 3,75 & 4,50 \\
\hline 2003 & 3,79 & $(1,37)$ & 5,33 & 4,87 & 6,10 & 5,45 & 12,19 & 6,73 & 4,41 & 4,78 \\
\hline 2004 & 2,82 & $(4,48)$ & 6,38 & 5,30 & 7,49 & 5,70 & 13,38 & 7,66 & 5,38 & 5,03 \\
\hline 2005 & 2,66 & 3,11 & 4,57 & 6,30 & 7,42 & 8,38 & 12,97 & 6,79 & 5,05 & 5,68 \\
\hline 2006 & 2,98 & 2,21 & 4,63 & 5,87 & 8,97 & 6,13 & 13,64 & 5,65 & 6,22 & 5,48 \\
\hline
\end{tabular}




\section{LAMPIRAN II.D}

\begin{tabular}{|c|c|c|c|c|c|c|c|c|c|c|}
\hline & & & & imploym & $\begin{array}{l}\text { abel II.D. } \\
\text { ent Sektc }\end{array}$ & ral (Rib & & & & \\
\hline Periode & Pertanian & $\begin{array}{l}\text { Pengga- } \\
\text { lian \& } \\
\text { Pertam- } \\
\text { bangan }\end{array}$ & $\begin{array}{l}\text { Industri } \\
\text { Peng- } \\
\text { olahan }\end{array}$ & $\begin{array}{l}\text { Listrik, } \\
\text { Gas, \& Air } \\
\text { Bersih }\end{array}$ & Bangunan & $\begin{array}{l}\text { Perda- } \\
\text { gangan, } \\
\text { Hotel \& } \\
\text { Restoran }\end{array}$ & $\begin{array}{l}\text { Peng- } \\
\text { angkutan } \\
\text { \& Komu- } \\
\text { nikasi }\end{array}$ & $\begin{array}{c}\text { Keuangan, } \\
\text { Sewa \& } \\
\text { Jasa } \\
\text { Perush. }\end{array}$ & $\begin{array}{c}\text { Jasa- } \\
\text { jasa }\end{array}$ & Total \\
\hline 1993 & 40.072 & 653 & 8.784 & 172 & 2.810 & 12.508 & 2.931 & 565 & 10.566 & 79.200 \\
\hline 1994 & 37.857 & 741 & 10.840 & 183 & 3.558 & 13.967 & 3.377 & 624 & 10.755 & 82.038 \\
\hline 1995 & 35.233 & 643 & 10.127 & 216 & 3.768 & 13.884 & 3.458 & 658 & 12.122 & 80.110 \\
\hline 1996 & 37.720 & 774 & 10.773 & 164 & 3.796 & 16.103 & 3.943 & 690 & 11.728 & 85.702 \\
\hline 1997 & 35.849 & 897 & 11.215 & 233 & 4.200 & 17.221 & 4.138 & 657 & 12.638 & 87.050 \\
\hline 1998 & 39.415 & 675 & 9.934 & 148 & 3.522 & 16.814 & 4.154 & 618 & 12.394 & 87.672 \\
\hline 1999 & 38.378 & 726 & 11.516 & 188 & 3.415 & 17.529 & 4.206 & 634 & 12.225 & 88.817 \\
\hline 2000 & 40.677 & 730 & 11.642 & 184 & 3.497 & 18.489 & 4.554 & 883 & 9.574 & 89.838 \\
\hline 2001 & 39.744 & 730 & 12.086 & 188 & 3.838 & 17.469 & 4.448 & 1.128 & 11.003 & 90.807 \\
\hline 2002 & 40.634 & 632 & 12.110 & 178 & 4.274 & 17.795 & 4.673 & 992 & 10.360 & 91.647 \\
\hline 2003 & 42.001 & 729 & 10.927 & 156 & 4.107 & 16.846 & 4.977 & 1.295 & 9.746 & 90.785 \\
\hline 2004 & 40.608 & 1.035 & 11.070 & 231 & 4.540 & 19.119 & 5.481 & 1.125 & 10.513 & 93.722 \\
\hline 2005 & 41.814 & 809 & 11.652 & 187 & 4.417 & 18.897 & 5.553 & 1.043 & 10.577 & 94.948 \\
\hline 2006 & 40.140 & 947 & 11.890 & 207 & 4.700 & 19.210 & 5.660 & 1.153 & 11.360 & 95.460 \\
\hline
\end{tabular}

\begin{tabular}{|c|c|c|c|c|c|c|c|c|c|}
\hline & & & Emplc & $\begin{array}{r}\text { Tabel } \\
\text { yment Sh }\end{array}$ & $\begin{array}{l}\text { II.D. } 2 \\
\text { are Sekto }\end{array}$ & ral (\%) & & & \\
\hline Periode & Pertanian & $\begin{array}{l}\text { Pengga- } \\
\text { lian \& } \\
\text { Pertam- } \\
\text { bangan }\end{array}$ & $\begin{array}{l}\text { Industri } \\
\text { Peng- } \\
\text { olahan }\end{array}$ & $\begin{array}{l}\text { Listrik, } \\
\text { Gas, \& Air } \\
\text { Bersih }\end{array}$ & Bangunan & $\begin{array}{c}\text { Perda- } \\
\text { gangan, } \\
\text { Hotel \& } \\
\text { Restoran }\end{array}$ & $\begin{array}{l}\text { Peng- } \\
\text { angkutan } \\
\text { \& Komu- } \\
\text { nikasi }\end{array}$ & $\begin{array}{c}\text { Keuangan, } \\
\text { Sewa \& } \\
\text { Jasa } \\
\text { Perush. }\end{array}$ & $\begin{array}{l}\text { Jasa- } \\
\text { jasa }\end{array}$ \\
\hline 1993 & 50,60 & 0,82 & 11,09 & 0,22 & 3,55 & 15,79 & 3,70 & 0,71 & 13,34 \\
\hline 1994 & 46,15 & 0,90 & 13,21 & 0,22 & 4,34 & 17,03 & 4,12 & 0,76 & 13,11 \\
\hline 1995 & 43,98 & 0,80 & 12,64 & 0,27 & 4,70 & 17,33 & 4,32 & 0,82 & 15,13 \\
\hline 1996 & 44,01 & 0,90 & 12,57 & 0,19 & 4,43 & 18,79 & 4,60 & 0,80 & 13,69 \\
\hline 1997 & 41,18 & 1,03 & 12,88 & 0,27 & 4,83 & 19,78 & 4,75 & 0,75 & 14,52 \\
\hline 1998 & 44,96 & 0,77 & 11,33 & 0,17 & 4,02 & 19,18 & 4,74 & 0,70 & 14,14 \\
\hline 1999 & 43,21 & 0,82 & 12,97 & 0,21 & 3,85 & 19,74 & 4,74 & 0,71 & 13,76 \\
\hline 2000 & 45,28 & 0,81 & 12,96 & 0,21 & 3,89 & 20,58 & 5,07 & 0,98 & 10,66 \\
\hline 2001 & 43,77 & 0,80 & 13,31 & 0,21 & 4,23 & 19,24 & 4,90 & 1,24 & 12,12 \\
\hline 2002 & 44,34 & 0,69 & 13,21 & 0,19 & 4,66 & 19,42 & 5,10 & 1,08 & 11,30 \\
\hline 2003 & 46,26 & 0,80 & 12,04 & 0,17 & 4,52 & 18,56 & 5,48 & 1,43 & 10,74 \\
\hline 2004 & 43,33 & 1,10 & 11,81 & 0,25 & 4,84 & 20,40 & 5,85 & 1,20 & 11,22 \\
\hline 2005 & 44,04 & 0,85 & 12,27 & 0,20 & 4,65 & 19,90 & 5,85 & 1,10 & 11,14 \\
\hline 2006 & 42,05 & 0,99 & 12,46 & 0,22 & 4,92 & 20,12 & 5,93 & 1,21 & 11,90 \\
\hline
\end{tabular}




\section{LAMPIRAN II.E}

\begin{tabular}{|c|c|c|c|c|c|c|c|c|c|c|}
\hline & & & Produkt & ivitas Ten & $\begin{array}{l}\text { abel II.E. } \\
\text { aga Kerj }\end{array}$ & ja Sektor & al (Rp Jt) & & & \\
\hline Periode & Pertanian & $\begin{array}{l}\text { Pengga- } \\
\text { lian \& } \\
\text { Pertam- } \\
\text { bangan }\end{array}$ & $\begin{array}{l}\text { Industri } \\
\text { Peng- } \\
\text { olahan }\end{array}$ & $\begin{array}{l}\text { Listrik, } \\
\text { Gas, \& Air } \\
\text { Bersih }\end{array}$ & Bangunan & $\begin{array}{l}\text { Perda- } \\
\text { gangan, } \\
\text { Hotel \& } \\
\text { Restoran }\end{array}$ & $\begin{array}{c}\text { Peng- } \\
\text { angkutan } \\
\text { \& Komu- } \\
\text { nikasi }\end{array}$ & $\begin{array}{l}\text { Keuangan, } \\
\text { Sewa \& } \\
\text { Jasa } \\
\text { Perush. }\end{array}$ & $\begin{array}{c}\text { Jasa- } \\
\text { jasa }\end{array}$ & Total \\
\hline 1993 & 4,82 & 207,86 & 30,75 & 24,48 & 26,35 & 15,63 & 17,74 & 208,83 & 10,77 & 14,54 \\
\hline 1994 & 5,13 & 193,45 & 28,00 & 25,85 & 23,90 & 15,06 & 16,68 & 208,34 & 10,87 & 15,09 \\
\hline 1995 & 5,75 & 237,92 & 33,23 & 25,35 & 25,49 & 16,35 & 17,67 & 219,19 & 9,96 & 16,73 \\
\hline 1996 & 5,54 & 210,15 & 34,86 & 37,93 & 28,53 & 15,25 & 16,85 & 221,89 & 10,64 & 16,86 \\
\hline 1997 & 5,89 & 185,31 & 35,25 & 30,00 & 27,68 & 15,09 & 17,18 & 246,87 & 10,24 & 17,38 \\
\hline 1998 & 5,29 & 239,49 & 35,24 & 48,75 & 20,98 & 12,64 & 14,52 & 192,56 & 10,04 & 14,99 \\
\hline 1999 & 5,55 & 219,00 & 31,59 & 41,44 & 21,22 & 12,12 & 14,23 & 174,20 & 10,37 & 14,91 \\
\hline 2000 & 5,33 & 229,75 & 33,12 & 45,55 & 21,90 & 12,14 & 14,28 & 130,82 & 13,55 & 15,47 \\
\hline 2001 & 5,63 & 230,47 & 32,96 & 48,24 & 20,87 & 13,36 & 15,80 & 109,30 & 12,17 & 15,86 \\
\hline 2002 & 5,70 & 268,96 & 34,63 & 55,35 & 19,76 & 13,67 & 16,30 & 132,62 & 13,42 & 16,42 \\
\hline 2003 & 5,72 & 229,89 & 40,43 & 66,19 & 21,82 & 15,23 & 17,17 & 108,41 & 14,89 & 17,37 \\
\hline 2004 & 6,09 & 154,73 & 42,45 & 47,20 & 21,22 & 14,18 & 17,68 & 134,33 & 14,54 & 17,67 \\
\hline 2005 & 6,07 & 204,10 & 42,17 & 62,01 & 23,43 & 15,55 & 19,71 & 154,76 & 15,19 & 18,44 \\
\hline 2006 & 6,51 & 178,15 & 43,25 & 59,22 & 23,99 & 16,24 & 21,98 & 147,83 & 15,02 & 19,34 \\
\hline
\end{tabular}

\begin{tabular}{|c|c|c|c|c|c|c|c|c|c|c|}
\hline & & & & $\begin{array}{r}\text { T } \\
\text { Upah Rit }\end{array}$ & $\begin{array}{l}\text { abel II.E. } \\
\text { il Sektora }\end{array}$ & 2 & & & & \\
\hline Periode & Pertanian & $\begin{array}{l}\text { Pengga- } \\
\text { lian \& } \\
\text { Pertam- } \\
\text { bangan }\end{array}$ & $\begin{array}{l}\text { Industri } \\
\text { Peng- } \\
\text { olahan }\end{array}$ & $\begin{array}{l}\text { Listrik, } \\
\text { Gas, \& Air } \\
\text { Bersih }\end{array}$ & Bangunan & $\begin{array}{l}\text { Perda- } \\
\text { gangan, } \\
\text { Hotel \& } \\
\text { Restoran }\end{array}$ & $\begin{array}{l}\text { Peng- } \\
\text { angkutan } \\
\text { \& Komu- } \\
\text { nikasi }\end{array}$ & \begin{tabular}{|c|} 
Keuangan, \\
Sewa \& \\
Jasa \\
Perush.
\end{tabular} & $\begin{array}{l}\text { Jasa- } \\
\text { jasa }\end{array}$ & Total \\
\hline 1993 & 2,51 & 7,49 & 4,81 & 7,74 & 5,21 & 5,48 & 7,62 & 9,73 & 5,89 & 5,09 \\
\hline 1994 & 2,70 & 9,84 & 4,60 & 7,47 & 5,33 & 5,28 & 6,72 & 9,04 & 5,90 & 5,09 \\
\hline 1995 & 2,77 & 8,80 & 5,01 & 7,87 & 5,68 & 5,50 & 7,05 & 10,43 & 6,31 & 5,02 \\
\hline 1996 & 2,90 & 8,08 & 5,25 & 8,19 & 5,72 & 5,69 & 7,14 & 11,76 & 6,47 & 5,64 \\
\hline 1997 & 3,00 & 8,46 & 5,76 & 10,39 & 6,12 & 5,89 & 7,36 & 11,85 & 7,11 & 3,00 \\
\hline 1998 & 3,53 & 10,54 & 6,40 & 11,52 & 6,93 & 6,62 & 8,48 & 12,59 & 7,50 & 5,38 \\
\hline 1999 & 2,86 & 8,64 & 4,55 & 8,59 & 5,09 & 4,98 & 6,33 & 8,39 & 6,55 & 5,20 \\
\hline 2000 & 2,87 & 7,64 & 5,01 & 8,33 & 5,26 & 5,00 & 6,81 & 9,37 & 14,85 & 5,35 \\
\hline 2001 & 3,21 & 8,50 & 6,09 & 9,38 & 5,63 & 5,87 & 7,78 & 11,35 & 8,37 & 6,37 \\
\hline 2002 & 3,17 & 8,79 & 6,39 & 9,83 & 5,91 & 6,27 & 7,78 & 11,43 & 8,46 & 6,45 \\
\hline 2003 & 3,20 & 9,20 & 6,55 & 10,27 & 5,95 & 6,60 & 7,78 & 11,80 & 8,77 & 6,59 \\
\hline 2004 & 3,24 & 9,75 & 7,32 & 11,30 & 6,44 & 7,20 & 8,52 & 12,82 & 10,62 & 7,32 \\
\hline 2005 & 3,05 & 10,51 & 8,15 & 12,47 & 6,96 & 7,88 & 9,28 & 13,97 & 11,25 & 8,09 \\
\hline 2006 & 2,76 & 10,90 & 8,73 & 13,24 & 7,24 & 8,30 & 9,72 & 14,64 & 11,92 & 8,59 \\
\hline
\end{tabular}

